\title{
Discourse on the Narrative of Coexistence for Intercultural Education
}

\author{
Dr. Seungeun Choi
}

Inha University, South Korea

Prof. Dr. Youngsoon Kim

Inha University, South Korea

\begin{abstract}
The changes are rapid and multi-faceted golablly; and, the issues and people in the world are interconnected and interrelated. Transformative cultural change engages a process at the crossroads of our social and political, while challenging historical narratives. Intercultural education aims to achieve a developing and sustainable way of living together in multicultural societies through the creation of understanding of, respect for and dialogue between the different cultural groups. Narrative is a characteristic of human consciousness that draws the sequence of experienced events and proposed actions into unified episodes. Moreover, narratives are closely tied to culture and identity and serve as a medium for constructing our understanding of reality. It is the core of intercultural education that the members who participate in society understand the narrative that mutual cultures have. This paper explores the discourse on the narrative of coexistence for intercultural education. The circular interpretation to the process means narratives are tools for conceptualizing and creating change among diverse others in differnet cultures.
\end{abstract}

Keywords: Narrative, Intercultural Education, Multicultural Society, Coexistence, Relationship, Interpretation, Other

\section{Introduction}

The era of globalism has changed the world; we move away from the selfcentered period of nationalism which has dominated the world for the past years. As Korean society is in transition toward a multicultural society, the coexistence of people with others is crucial point of view. The narrative is dynamic and living as change occurs at the local and global levels. Transformative cultural change engages a process at the crossroads of our social and political, while challenging historical narratives. The exploration of culture and diversity is an interactive, continually expanding and shifting process that requires the inclusion of multiple voices and lenses. Educational knowledge and activities are part of the dynamic interchange of building relationships and creating bridges among different cultures. Intercultural education advocates for positive change are upholding the professional values of change toward social justice and respect for human dignity.

This paper explores the discourse on the narrative of coexistene for intercultural education. Every culture has its own narrative. It is the core of intercultural education that the members who participate in society understand the narrative that mutual cultures have. Thus, the narrative of coexistence for intercultural education deals with the dynamical exchange of these narratives.

\section{Theoretical Background}

\section{Intercultural Education}

In a world experiencing rapid change, and where cultural, political, economic and social upheaval challenges traditional ways of life, education has a major role to play in promoting social cohesion and peaceful coexistence. Moreover, education can make an important and meaningful contribution to sustainable and tolerant societies (UNESCO, 2006: 8). Intercultural Education is a response to the challenge to provide quality education for all. 
The international cultural, political and economic globalization of intercultural education is essential to its understanding. Intercultural education is "the intentional and systematic effort to foster intercultural learning ${ }^{1}$ through curriculum design, including pre-departure, on-site, and re-entry activities, and/or course content emphasizing subjective culture and intercultural interaction, and/or the guided facilitation of intercultural experience" (Bennett, 2009: 8).

Interculturality in education is "a space for dialogue which recognises and values the wealth of cultural, ethnic and linguistic diversity in the country, promotes the affirmation and development of different cultures which co-exist in the world and constitutes an open process towards cultural exchange with the global society" (Aikman, 1997: 469). This vision echoes themes found in most conceptualizations of intercultural education- especially those offered by people and organizations in positions of power and privilege. Moreover, intercultural education recognizes that "a genuine understanding of cultural differences and similarities is necessary in order to build a foundation for working collaboratively with others; a pluralistic society can be an opportunity for majority and minority groups to learn from and with one another" (Cushner 1998: 4). These views synthesize the sorts of goals most often identified within "definitions of intercultural education: the facilitation of intergroup and intercultural dialogue, an appreciation of diversity, and cultural exchange" (Gorski, 2008:7).

In order to strenghthen decomocratic education system, UNESCO (2006: 18) suggestes that two approaches: multicultural education and Intercultural education. Multicultural education uses learning about other cultures to produce acceptance, or at least tolerance, of these cultures. Intercultural education aims to go beyond passive coexistence, to achieve a developing and sustainable way of living together in multicultural societies through the creation of understanding of, respect for and dialogue between the different cultural groups.

\section{The Concept of Narrative}

The maian claim for the use of narrative in educational research is that "humans are storytelling organism who, individually and socially, lead storied lives. The study of narrative, thereforem is the study of the ways humans experience the world" (Connelly \& Clandinin, 1990: 2). Narrative is based firmly in the premise that, as human beings, we come to understand and give meaning to our lives through story (Andrews, Squire \& Tambokou, 2008). As everyone has its own narrative, every culture has its own narrative. Narrative inquiry then has evolved from the growing participatory research movement that foregrounds a greater sensitivity to social and cultural differences. "Narrative inquiry embraces narrative as both the method and the phenomena of study" (Pinnegar \& Danes, 2007: 4) and "characteristically begins with the researcher's autobiographically oriented narrative associated with the research puzzle" (Clandinin \& Connelly, 2000: 40).

Exploring the diverse experiences of learning and teaching through individual and collective narratives allowed to begin to understand the cultural embeddedness of learning and teaching knowledges and how these knowledges are "narratively composed, embodied in people and expressed in practice" (Clandinin \& Connelly, 2000: 124).

Narrative can produce "insightful accounts of processes which go beyond the particular story itself" (Pring, 1999: 6), can contribute much to effective intercultural communication and education. Intercultural education does not just happen (Otten, 2003), through narrative, it can be explicit about diversity in the contexts.

Narrative structuring is a characteristic of human consciousness that draws the sequence of experienced events and proposed actions into unified episodes. By being included in a plot, events take on significance and meaning. Narratives are but a recapitulation of the structure of everyday experience and action (Polkinghorne, 1991: 142). Achieving narrative coherence of events and actions in our life stories is not a once-and-for-all feat. Rather, it is an ongoing task, sometimes a struggle, and success is a real accomplishment (Polkinghorne, 1991: 145).

\section{Narrative of Coexistence for Intercultural Education}

Why is it important to understand each narrative in intercultual education? It is necessary for coexistence. In this paper, it is called the narrative of coexistence. This study is to examine the discourse on the narrative of coexistence. Three issues in the discourse are discussed below. They do not exist individually, but are linked organically in a multicultural society.

\footnotetext{
1 The definition of intercultural learning is "acquiring increased awareness of subjective cultural context (world view), including one's own, and developing greater ability to interact sensitively and competently across cultural contexts as both an immediate and long-term effect of exchange." (Bennett, 2009: 2).
} 


\section{With the Other beyond Sympathy}

Levinas (1946) uses phenomenological structure, his general aim is to show that time is not the achievement of an isolated subject, but the very relationship which that subject has with the Other. This in turn leads to "a discussion of solitude and materiality, which is the existent identical to itself and occupied with itself" (Hand, 1989: 37).

The dissolution and decentralization of the subject, which has become the most acute issue in contemporary philosophy, has greatly contributed to reflection on the self-centered thought which is existed in the western culture. The question is how human's life goes after the deconstruction. Levinas criticizes western philosophy as a philosophy of totality, or a philosophy of war, that intentionally dominated 'the other' and 'the other thing'. He argues that 'philosophy of other' that represents the personal value of an individual who can not be reverted to anything and the responsibility to others.

(...) existence is pluralist. Here the plural is not a multiplicity of existents; it appears in existing itself. (...) To be sure, the other (l'Autre) that is announced does not possess this existing as the subject possesses it; its hold over my existing is mysterious. It is not unknown but unknowable, refractory to all light. But this precisely indicates that the other is in no way another myself, participating with me in a common existence. The relationship with the other is not an idyllic and harmonious relationship of communion, or a sympathy through which we put ourselves in the other's place; we recognize the other as resembling us, but exterior to us; the relationship with the other is a relationship with a Mystery. The other's entire being is constituted by its exteriority, or rather its alterity, for exteriority is a property of space and leads the subject back to itself through light. (Levinas, 1946: 85)

Levinas does not regard the otherness of the other as a 'alter ego' that distinguishes itself from another, or the other being able to communicate with one another through sympathy or compassion. The otherness of the other is defined as absolute exogenousness which can not be compared with self.

The philosophy of Levinas is concerned with human suffering and concrete life, emphasizing the responsibility and solidarity of the sufferer. But he discusses it philosophically, rather than appealing to responsibility and solidarity, and portrays human life concretely and practically. Levinas' philosophy emphasizes the responsibility and solidarity of neighbors and others, while at the same time evaluating the position of human beings without making human beings absolute and not returning them to an object of natural science.

In this context, we have to accept the narrative of other without color, rather then treat the efficiency of diversity by judging the value of using other cultures in a multicultural society. What is needed in this era is, above all, the ethics of the other.

\section{Democratic Relationship in Diversity}

Global change is negotiated in the spaces between and across the personal and the social, political aspect. Multiple forms of diversity, including race, ethnicity, nationality, religion, gender, sexual orientation, disability, and class, were determinated as core dimensions along which social system overlay structural mechanism.

Sleeter (1996) recognizes that, in order to reform power relationships in schools, we must first understand those relationships in a larger societal and global context. Grant and Sleeter (1998:164) include "promotion of awareness of the social issues involving unequal distribution of power and privilege that limits the opportunity of those not in the dominant group. " By nurturing this awareness, multicultural education uncovers "policies and practices that are advantageous for some students at the expense of others" (Nieto, 2000: 315).

The power of relationships is vital to social justice. Relationship are key to our work with the people we serve and their families and communities, other professionals, and decision makers. Through relationship, an environment can be created that cultivates social and economic justice, respect for human rights.

"The pursuit of full humanity cannot be carried out in isolation or individualism, but only in fellowship and solidarity; therefore, it cannot unfold in the antagonistic relations between oppressors and oppressed. No one can be authentically human while he or she prevents others from being so. " (Freire, 1994: 85)

Cultural synthesis affirms the worldview of actors who critically analyze the current reality and together "intervene as Subjects in the historical process" (Freire, 1994: 162). Narratives, which are socially constructed, are closely tied to culture and identity and serve as a medium for constructing our understanding of reality. The circular nature to this process means 
narratives are tools for conceptualizing and creating change. It is in re-negotiating the existing definitions of words or phrases that a new meaning or social purpose can be found for greater benefits to humankind.

Everyone is entitled to all the rights and freedoms set forth in this Declaration, without distinction of any kind, such as race, color, sex, language, religion, political or other opinion, national or social origin, property, birth or other status. (United Nations, 1948)

As UN mentioned, we have to embrace multiple identities and have equity in multicultural society. The democratic relationship can be built by accepting diversity. Diversity holds the potential to ignite creativity, which underlies the development of new change models. The goal of the diversity conversation process was to create a format for engaging the discussion of diversity and the dismantling of oppression within a context that invites participation and inclusion.

\section{Hermeneutic Communication through Interaction}

Human existence finds at the very core of its being that it is perpetually underway to language. According to Ricoeur, it through language that the responsible human subject is revealed, a subject who speaks and acts in a world that is immersed in constant conflict, a subject who continuously suffers in life but still desires to live.

Ricoeur (1985) suggests the utilization of the overflowing creativity of language in highlighting the meaning of the self. The self, according to him, is like a text. This means that the self as an actor is like the unfolding of the text into a meaningful story. To understand oneself is to interpret oneself before this story. The narrative then is a story of a life lived expressed in and through language.

The narrative has "the same referential function of the metaphor. The metaphor brings us to a world, a world that is not known through a direct description. Narration brings us to the temporal dimensions of our existence by means of the poetic power of the narrative, a detour through the text of one's life story. The narrative then illuminates human action and makes manifest its temporality. Thus, human action is shaped by mimetic activity which unfolds in the plot" (Ricoeur, 1985: 87)

Ricoeur's idea of narrative "is careful to maintain the distinction between the inside of the text and its outside" (Ricoeur, 1991: 26). Moreover, "a life is no more than a biological phenomenon as long as it has not been interpreted. " (Ricoeur, 1991: 27-8). Ricoeur suggests that human lived or social reality is mediated by symbolic representations, which are waiting for interpretation. He seeks to develop "a theory of language which would provide the springboard for a hermeneutic philosophy". The theory is premised upon a fundamental distinction between "system and discourse" (Ricoeur 1981: 1113).

Ricoeur emphaizes the function respectively in the theories of discourse, text, and narrative. The understanding of meanings and the problems of interpretation and translation are on the rise. These are essential to the understanding of the relations, not only between past and present in a society, but also between diverse cultures. Thus, the Hermeneutics of communication is applicable both to the communication between past and present and to that between diverse cultures.

\section{Conclusion}

The demographic and cultural composition of societies is rapidly changing as a result of greater mobility of peoples and persons. Racism, ethno-centrism, or xenophobia constitutes a serious threat to the life and well-being of present societies and to the dignity and worth of human beings.

The communicative situation of narrative is one that results in the "possibility of constructing a minority voice that confirms the hegemonic status quo" (Briggs, 2002: 911-912) rather than one that leads the individual with different life expedirence. The coexistence narrative shows how culturally interacts with others.

Cultural diversity forms part of a socio-economic and political context and is related to power structures that influence the ways in which components of the world's cultural heritage are perceived and socially constructed. Among the most significant skills are the ability to listen and observe beyond one's socially constructed cultural base. While there is much discourse in the narrative about cultural competence and diversity, the language often appears contradictory and inadequate without a platform from which to build. What is needed is a context for understanding the dynamics underlying the issues and an exploration about why it is important to engage in learning about learning across cultures. 
Intercultural education pursuits the peaceful coexistence. The narrative of coexistence does not mean one-way learning, but interactive communication with others through equitable relationship and circulative interpretation. It can recognize and respect the cultural context and the transformative power of relationship. Intercultural education, a congruent learnig with the core value domain of democratic society, supports a re-conceptualization of diversity, relationships and power.

\section{Acknowledgement}

This work was supported by the Ministry of Education of the Republic of Korea and the National Research Foundation of Korea (NRF-2015S1A5A2A03048350).

\section{References}

[1] Andrews, M., Squire, C., \& Tamboukou, M. (Eds. ). (2008). Doing narrative research. London: Sage.

[2] Bennett, M. J. (2009). Defining, measuring, and facilitating intercultural learning: a conceptual introduction to the intercultural education double supplement. Intercultural Education, 20(1), 1-13.

[3] Briggs, C. (2002). Interviewing, power/knowledge, and social inequality. In J. Gubrium and J. Holstein (eds) The Handbook of Interview Research: Context and Method. 911-922. Thousand Oaks: Sage Publications.

[4] Connelly, F. M., \& Clandinin, D. J. (1990). Stories of experience and narrative inquiry. Educational researcher, 19(5), 2-14.

[5] Clandinin, D. J., \& Connelly, F. M. (2000). Narrative inquiry: Experience and story in qualitative research. San Francisco, Ca.: Jossey-Bass.

[6] Freire, P. (1994). Pedagogy of the oppressed. New York: Continuum Publishing Company.

[7] Gorski, P. C. (2008). Good intentions are not enough: A decolonizing intercultural education. Intercultural education, 19(6), 515-525.

[8] Grant, C. \& Sleeter, C. (1998). Turning on learning: five approaches to multicultural teaching plans for race, class, gender, and disability. Upper Saddle River, NJ: Prentice-Hall.

[9] Hand, S. (Ed. ) (1989). The Levinas reader. Malden, MA: Blackwell Publishers.

[10] Levinas, E. (1946). Le Temps et L'autre. R. A. Cohen (Trans. ) (1987). Time and the Other. Duquesne University Press.

[11] Nieto, S. (2000). Affirming diversity: the sociopolitical context of multicultural education. New York: Longman.

[12] Otten, M. (2003). Intercultural learning and diversity in higher education. Journal of Studies in International Education, 7(1), 12-26.

[13] Pinnegar, S., \& Daynes, J. G. (2007). Locating narrative inquiry historically. Handbook of narrative inquiry: Mapping a methodology, 3-34.

[14] Polkinghorne, D. E. (1991). Narrative and self-concept. Journal of narrative and life history, 1(2-3), 135-153.

[15] Pring, R. (1999). Reflecting on the reflective practitioners. In Ai-Yen Chen \& John van Maanen (Eds. ), The reflective spin: Case studies of teachers in higher education transforming action, 3-13. Singapore: World Scientific.

[16] Ricoeur, P., \& Thompson, J. B. (1981). Hermeneutics and the human sciences: Essays on language, action and interpretation. Cambridge university press.

[17] Ricoeur, P. (1985). Time and Narrative (Vol. 3). K. Blamey \& D. Pessauer (Trans. ) London and Chicago: University of Chicago Press.

[18] Ricoeur, P. (1991). Life in quest of narrative. In David Wood (Ed. ). On Paul Ricoeur; Narrative and Interpretation. London: Routledge.

[19] Sleeter, C. (1996). Multicultural education as social activism. Albany, NY: State University of New York Press.

[20] United Nations. (1948). Universal declaration of human rights. http://www. un. org.

[21] United Nations Educational, Scientific and Cultural Organization. (2006). Guidelines of Intercultural Education. http://www. unesco. org. 